\title{
PENGARUH IKLIM ORGANISASI TERHADAP KINERJA \\ PT. INDUSTRI TELEKOMUNIKASI INDONESIA (INTI) PERSERO BANDUNG
}

\author{
Boby Novika \\ Universitas Mohammad Natsir Bukittinggi \\ benovika@gmail.com
}

\begin{abstract}
The purpose of this study was to determine whether there was a positive and significant influence of organizational climate on performance in PT INTI Bandung. This study used a quantitative method. Data were collected through literature study and field study with observation, interview, and questionnaire towards 42 respondents. The number of samples in this study was obtained through simple random sampling technique. Research instruments were grouped into two variables, that is variable $X$ (Climate Organization) and variable $Y$ (Employee Performance). Data obtained from questionnaires were tabulated based on frequent frequencies, presented and analyzed qualitatively. Meanwhile, to find the influence between the two variables of this study the researchers used simple linear regression analysis techniques. Based on the results of the research it could be concluded that there was a positive and significant influence of organizational climate on companies performance of PT. INTI Bandung shown by simple linear regression equation $Y=5,53+0,688 X$. That is, the regression coefficient of 0.688 stated that each addition (due to the + sign) one score of the organization's climate value would give a score increase of 5.53 to the companies performance.
\end{abstract}

Keywords: Organizational climate, performance, Employee

\section{Pendahuluan}

Organisasi publik merupakan organisasi yang tujuan utamanya adalah memberikan pelayanan yang sebaik-baiknya kepada publik/masyarakat. Salah satu bentuk organisasi publik yang pengelolaannya ditujukan untuk memberikan pelayanan kepada publik dalam rangka mencapai kemakmuran masyarakat adalah Badan Usaha Milik Negara (BUMN). Berdasarkan Undang-undang No.19 Tahun 2003 tentang Badan Usaha Milik Negara (BUMN), BUMN merupakan Badan Usaha Milik Negara yang bertujuan memperoleh keuntungan yang sebesarbesarnya sebagai penghasil kekayaan negara baik yang pengelolaannya dilakukan oleh pemerintah maupun pihak swasta untuk mencapai kesejahteraan publik/masyarakat.

Dalam perkembangannya, sejak era reformasi, terjadi banyak penyimpangan dalam pengelolaan BUMN di Indonesia. Tujuan utama keberadaan BUMN yang dimaksudkan sebagai penghasil sebesar-besarnya kekayaan negara tersebut ternyata tidak tercapai dengan baik. Secara umum, banyak BUMN yang ada di Indonesia ternyata tidak sepenuhnya berada dalam kondisi sehat. Disinyalir, terdapat banyak kesalahan dalam pengelolaan BUMN 
di Indonesia. Banyak di antaranya dalam kondisi limbung akibat faktor eksternal maupun internal yang sulit dihindari. Pada 2007, dari total 160 BUMN yang ada, hanya $25,5 \%$ yang sehat sekali; $20,8 \%$ sehat; $18,2 \%$ kurang sehat; serta $35,8 \%$ tidak sehat. Data lain pada tahun yang sama menunjukkan bahwa BUMN merupakan bidang usaha terkorup kedua di Indonesia setelah birokrasi dengan jumlah korupsi mencapai Rp 11triliun (dikutip dari harian Media Indonesia, Juli 2007).

PT. Industri Telekomunikasi Indonesia (INTI) Persero Bandung (selanjutnya disebut PT. INTI) merupakan salah satu Badan Usaha Milik Negara yang bergerak dalam bidang penyedia layanan industri jaringan telekomunikasi nasional. Sejak berdiri pada 1926, PT.INTI telah mengalami perkembangan fungsi dan orientasi usaha. Pada 1990an, PT.INTI merupakan perusahaan yang menjadi pemasok utama jaringan telekomunikasi nasional. Selain itu, PT.INTI juga telah menjual produknya ke luar negeri seperti India, Banglades, serta Myanmar.

Perubahan situasi kompetisi pasar yang semakin ketat dan regulasi telekomunikasi yang makin terbuka menjadikan PT.INTI melakukan perubahan core bisnis dari manufaktur ke jasa infocom sejak 2002 yang mengakibatkan perubahan dalam visi dan misi perubahan sehingga tugas dan tanggung jawabnya juga ikut berubah. Selain itu, kerjasama teknologi tidak lagi bersifat single core, namun dilakukan secara multisource dengan mendirikan anak-anak perusahaan dan usaha patungan.

Berdasarkan Akte Pendirian Perusahaan, maksud dan tujuan pendirian PT. INTI ialah turut melaksanakan dan menunjang kebijakan dan program pemerintah di bidang ekonomi dan pembangunan nasional pada umumnya dan khususnya di bidang industri infokom dengan memperhatikan prinsip-prinsip yang berlaku bagi perseroan. Di samping maksud dan tujuan tersebut di atas, secara komersial perusahaan bertujuan untuk menjadi perusahaan yang menguntungkan, makmur dan berkelanjutan.

Namun pada kenyataannya, berdasarkan data sekunder yang didapatkan melalui media cetak, annnual report PT. INTI serta sumber-sumber lain, peneliti menemukan indikasi bahwa terjadi penurunan kinerja karyawan PT. INTI sejak era reformasi bergulir. Hal tersebut terindikasikan sebagai berikut: 1) berdasarkan laporan tahunan perusahaan dalam annual report PT. INTI, RKAP dan realisasi tahun 2008, tingkat kedisiplinan karyawan masih rendah. Hal ini dilihat dari tingkat pencapaian absensi karyawan sepanjang 2008 yang masih di bawah RKAP; 2) realisasi produksi jasa masih banyak yang belum mencapai target; 3) Prestasi PT. INTI makin menurun. Dalam hal ini, pada 2008 Kementerian BUMN memasukkan PT. INTI sebagai BUMN yang kurang berkembang. Bahkan pada 2009, PT. INTI termasuk salah satu BUMN yang direncanakan akan diakuisisi oleh pemerintah (sumber: http:AnjarPriandoro.blog, 2009); serta 4)Tingkat kesehatan perusahaan dikategorikan 'Kurang Sehat' dengan tingkat penggolongan 'BBB'. Tingkat kesehatan perusahaan diukur melalui produktivitas penjualan produk dan jasa perusahaan. Berdasarkan data dari hasil evaluasi terhadap kinerja PT.INTI tahun 2008, skor kinerja PT. INTI hanya $61,50 \%$ yang berarti dikategorikan rendah (Annual Report PT INTI 2008). 
Berdasarkan penelusuran lebih lanjut, menurunnya kinerja PT. INTI tersebut diduga dipengaruhi oleh iklim perusahaan yang kurang kondusif. Terdapat indikasi yang menunjukkan bahwa Iklim Organisasi di PT. INTI dalam beberapa tahun terakhir berlangsung kurang kondusif. Hal tersebut terindikasikan sebagai berikut: 1) ketidakkondusifan kondisi internal perusahaan; 2) pergantian kepemimpinan pada tingkat Top Level Management yang terjadi begitu cepat dan sporadis ternyata ikut mempengaruhi inovasi di PT. INTI; 3) menurut keterangan yang diperoleh dari Asisten Manajer Sekretaris Perusahaan, struktur organisasi perusahaan bersifat lini dan staf ini membuat masing-masing divisi lebih mementingkan divisinya sendiri sehingga keutuhan (integrity) perusahaan tidak terjaga; serta 4) dukungan manajemen perusahaan masih belum optimal. Hal ini menyangkut penyediaan peralatan kerja bagi karyawan yang belum memadai untuk menyokong bisnis IT berbasis jasa.

\section{Tinjauan Kepustakaan}

\section{Iklim Organisasi}

Setiap organisasi memiliki ciri khas tersendiri. Ciri khas tersebut akan membedakan satu organisasi dengan organisasi lainnya. Setiap organisasi dipengaruhi oleh lingkungan internal dan lingkungan eksternal. Lingkungan internal organisasi merupakan 'atmosfir organisasi' yang dapat menunjukkan suasana kebatinan di dalam organisasi. Dalam bahasa sederhana, atmosfir organisasi tersebut disebut juga iklim organisasi. Luthans (dalam Simamora, 2004) mengemukakan bahwa iklim organisasi merupakan lingkungan internal atau psikologi organsiasi. Luthans menekankan bahwa iklim akan menentukan praktek dan kebijakan SDM yang diterima anggota organisasi. Iklim organisasi juga membedakan satu organisasi dengan organisasi lainnya. Pada pandangan serupa, Stringer sebagaimana dikutip Wirawan (2007) menyatakan bahwa iklim organisasi adalah koleksi dan pola lingkungan organisasi yang mendorong timbulnya motivasi. Hal ini menyiratkan bahwa iklim organisasi merupakan kumpulan suasana internal di dalam sebuah organisasi yang mampu menciptakan sekaligus menghilangkan motivasi para anggotanya.

Kedua pendapat di atas memberikan pemahaman bahwa iklim organisasi menyangkut suatu kondisi yang berada di dalam lingkungan internal organisasi. Kondisi ini akan turut mempengaruhi sikap dan perilaku anggota serta cara kerja suatu organisasi. Dengan kata lain, iklim organisasi akan turut menentukan keberhasilan suatu organisasi. Sejalan dengan itu, Berry (2001) memberikan defenisi tentang iklim organisasi sebagai suatu pemahaman akan kehangatan sikap dari anggota organisasi dan tingkat dukungan organisasi kepada anggotanya. Iklim organisasi juga menggambarkan reaksi individu terhadap terhadap organisasi.

Berdasarkan keterangan di atas dapat dipahami bahwa iklim organisasi tidak hanya menyangkut aspek fisik dalam organisasi namun juga berkenaan dengan aspek persepsi anggota organisasi serta lingkungan kerja/suasana yang mencerminkan norma/keyakinan dalam organisasi. Iklim organisasi lebih 
menekankan kepada suasana di lingkungan internal atau yang biasa disebut juga atmosfir organisasi. Iklim organisasi akan sangat dipengaruh oleh setiap perubahan yang terjadi baik menyangkut struktur, budaya dan fungsi di dalam organisasi.

Untuk mengukur iklim organisasi, Berry (2001) mengemukakan dimensi iklim organisasi sebagai berikut: (1) kejelasan organisasi; menyangkut struktur organisasi, penanaman visi dan nilai-nilai organisasi serta pemahaman anggota terhadap harapan organisasi; (2) standar kerja; menyangkut peraturan yang ditetapkan pimpinan, penentuan batas tekanan kepada karyawwan dan penciptaan kondisi aman dan menyenangkan di dalam organisasi; (3) semangat kerja kelompok; menyangkut upaya organisasi menekankan peningkatan prestasi kepada anggota organisasi, kehangatan bekerja serta kebanggaan terhadap organisasi; (4) tanggung jawab; menyangkut pemberian imbalan atas prestasi dan bukan senioritas, favoritisme dan selanjutnya; (5) imbalan; penghargaaan/ promosi atas dasar prestasi.

\section{Kinerja Organisasi/Perusahaan}

Organisasi adalah sesuatu yang abstrak sementara wujud nyata dari sebuah organisasi adalah semua tindakan dan proses kerja sama yang dilakukan orangorang yang menggerakkan organisasi tersebut. Tindakan tersebut akan berujung pada kinerja organisasi. Dengan kata lain, kinerja organisasi tidak terlepas dari kinerja orang-orang yang ada di dalamnya. Wibowo (2007) menjelaskan bahwa kinerja organisasional merupakan produk dari banyak faktor, termasuk struktur organisasi, pengetahuan, sumber daya bukan manusia, posisi strategis dan proses sumber daya manusia. Dalam penekanan lebih luas, Wibowo (2007) menyatakan pengertian kinerja sebagai berikut:

Kinerja dalam arti sempit adalah hasil kerja atau prestasi kerja. Kinerja dalam arti luas bukan hanya dinyatakan sebagai hasil kerja tetapi lebih menekankan kepada bagaimana proses kerja belangsung. Kinerja adalah tentang melakukan dan hasil yang dicapai dari pekerjaan tersebut. Kinerja adalah tentang apa yang dikerjakan dan bagaimana cara mengerjakan sesuatu. Kinerja dalam sebuah organisasi dilakukan oleh segenap sumber daya manusia dan organisasi. Dengan demikian kinerja organisasi dapat ditunjukkan oleh bagaimana proses berlangsungnya kegiatan untuk mencapai tujuan tersebut.

Mengacu kepada pandangan Wibowo di atas, peneliti berasumsi bahwa kinerja organisasi tersebut merupakan hasil dari akumulasi berbagai faktor yang terdapat di dalam organisasi. Terdapat sebuah benang merah yang menunjukkan keterkaitan antara iklim organisasi dengan kinerja karyawan di dalam organisasi. Hal ini ditunjukkan oleh adanya pengaruh struktur, suasana kerja, pemahaman nilai, dukungan serta tingkat harapan yang terdapat pada perangkat organisasi yang akan mempengaruhi kinerja itu sendiri.

Dalam mengukur kinerja individu dalam sebuah organisasi dapat dilihat dari lima dimensi sebagaimana yang dikemukakan oleh TR. Mitchel (dalam Sedarmayati, 2001) sebagai berikut: (1) Quality of work (Kualitas Kerja); (2) 
Initiative (Inisiatif); (3) Proptness (Ketepatan Waktu); (4) Communication (Komunikasi); (5) Capability (Kapabilitas).

\section{Gambar 1: Alur Kerangka Berpikir Penelitian}

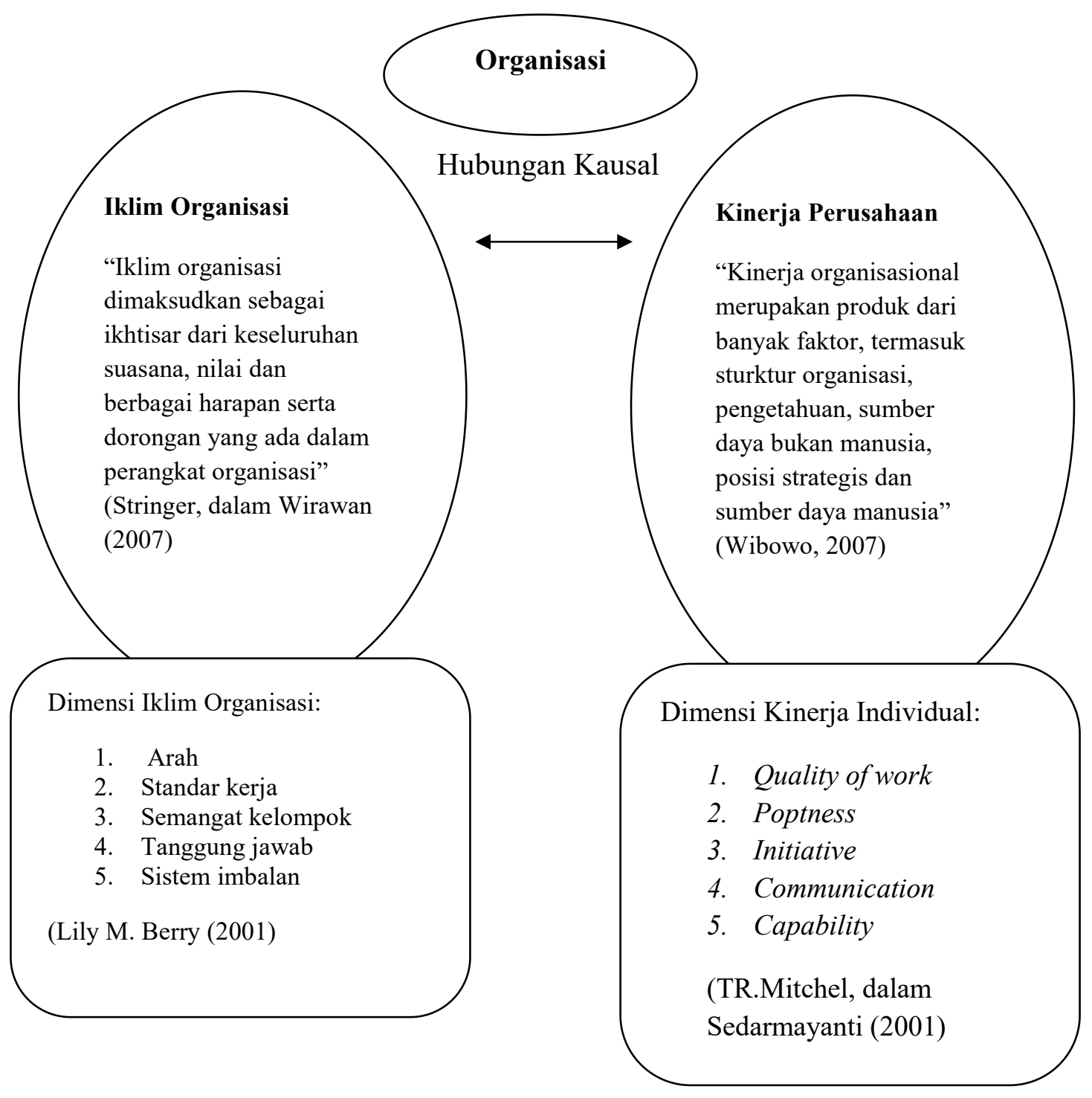

(Sumber: Peneliti, 2009)

\section{Metode Penelitian}

Penelitian ini menggunakan metode kuantitatif untuk menjelaskan pengaruh variabel bebas (iklim organisasi) terhadap variabel terikat (kinerja karyawan). Teknik pengumpulan data yang digunakan dalam penelitian ini adalah sebagai 
berikut: (1) studi literatur, yaitu penjelasan kepustakaan guna mendapatkan informasi teoritis yang ada relevansinya dengan masalah yang sedang diteliti seperti iklim organisasi dan kinerja karyawan; (2) studi lapangan (observasi) melalui teknik observasi non participatory; (3) angket tertutup; serta (4) teknik wawancara bebas.

Penentuan ukuran sampel yang digunakan dalam penelitian ini mengacu kepada rumus Salusu (2006): $\mathrm{N}=\mathrm{N} / 1+\mathrm{N}(\mathrm{e})^{2}$. Berdasarkan jumlah karyawan yang terdapat di PT INTI yakni sebanyak 695 orang, maka dengan menggunakan rumus tersebut diperoleh jumlah sampel sebesar 42 orang, dengan e sebesar $15 \%$. Analisis data dilakukan secara kuantitatif yang ditujukan untuk menganalisis besaran pengaruh antara variabel $\mathrm{X}$ dan variabel $\mathrm{Y}$. Skala pengukuran yang digunakan adalah skala pengukuran Likert berupa data ordinal karena data yang akan dicari menyangkut sikap, pendapat dan persepsi responden. Selanjutnya, setelah ditabulasikan data penelitian dimasukan ke dalam berbagai kategori dengan mengisi daftar indeks. Indeks yang digunakan ditujukan untuk mengukur indeks jawaban setiap dimensi berdasarkan jumlah indikatornya. Sementara itu, antara variabel bebas dan variabel terikat terdapat hubungan kausal. Oleh sebab itu, untuk memprediksi besaran nilai variabel terikat berdasarkan kontribusi (pengaruh) nilai variabel bebas dilakukan analisis regresi linear sederhana.

Berdasarkan ketentuan di atas, maka diperoleh indeks untuk satu indikator sebagai berikut:

1. Nilai indeks minimum: $1 \times 1 \times 42=42$

2. Nilai indeks maksimum: $5 \times 1 \times 42=210$

3. Interval $=210-42=168$

4. Jarak interval $=168: 5=33,6$

Dalam penelitian ini, peneliti mengajukan hipotesis penelitian sebagai berikut: "Terdapat pengaruh yang positif dan signifikan antara iklim organisasi terhadap kinerja karyawan PT.INTI Persero Bandung." Berdasarkan hipotesis tersebut, peneliti mengemukakan hipotesis statistik sebagai berikut:

$H a: p \neq 0$; "terdapat pengaruh yang positif dan signifikan antara iklim organisasi terhadap kinerja karyawan PT.INTI Persero Bandung," dan

Ho $: p=0$; "tidak terdapat pengaruh yang positif dan signifikan antara iklim organisasi terhadap kinerja karyawan PT.INTI Persero Bandung."

Untuk mengetahui signifikansi pengaruh antara iklim organisasi terhadap kinerja karyawan dapat dilihat pada tabel anova melalui bantuan SPSS dengan ketentuan sebagai berikut:

- Jika nilai probabilitas 0,15 lebih kecil atau sama dengan nilai probabilitas Sig atau $[0,15 \leq$ Sig], maka Ho diterima da Ha ditolak.

- Jika nilai probabilitas 0,15 lebih besar atau sama dengan nilai probabilitas Sig atau $[0,15 \geq \mathrm{Sig}]$, maka Ha diterima dan Ho ditolak. 
Untuk menentukan korelasi dan pengaruh dua variabel yang diteliti, peneliti menggunakan rumus persamaan regresi linear sederhana: $Y^{\prime}=a+b X$, yang mana: (1) $\mathrm{Y}^{\prime}=$ Subjek/nilai dalam variabel dependen yang diprediksikan; (2) $a=$ harga $\mathrm{Y}$ bila $\mathrm{X}=0$; (3) $\mathrm{b}=$ Angka arah/koefisien regresi; serta (4) $\mathrm{X}=$ Subjek pada variabel independen yang punya nilai tertentu.

\section{Hasil Penelitian dan Pembahasan}

Iklim organisasi dapat dipahami sebagai keseluruhan kondisi internal/atmosfir yang terdapat di dalam organisasi yang akan mempengaruhi perkembangan suatu organisasi. Iklim organisasi menyangkut kejelasan arah, sistem imbalan, semangat kerja kelompok, tanggung jawab serta standar kerja. Keempat dimensi inilah yang menjadi acuan di dalam mengukur iklim organisasi di PT. Industri Telekomunikasi Indonesia Bandung.

Berdasarkan perolehan data pada 2010, dapat diketahui bahwa 21,42\% responden menyatakan sangat setuju tentang pemahaman visi perusahaan. Mayoritas lainnya yakni sekitar 76,19\% menyatakan setuju. Hal ini menunjukkan bahwa indikator pemahaman visi perusahaan sudah terpenuhi dengan baik. Berikutnya, pada indikator pemahaman nilai-nilai budaya perusahaan, mayoritas responden yakni $69,04 \%$ menyatakan tidak memahami budaya perusahaan dengan baik. Hal tersebut lebih dikarenakan terlalu seringnya terjadi pergantian pimpinan. Hanya dalam kurun waktu 2 tahun (2007-2009), pimpinan PT. INTI telah berganti sebanyak 3 kali. Akibatnya, nilai-nilai budaya perusahaan tidak pernah terinternalisasikan secara optimal, sebab berganti pimpinan sama artinya dengan berganti pula budaya organisasi yang dipakai. Indikator selanjutnya yang diukur adalah penilaian kemajuan perusahaan. Untuk indikator ini mayoritas responden $(76,18 \%)$ setuju bahwa mereka tidak melihat adanya kemajuan perusahaan secara signifikan pasca reformasi-2009. Hal tersebut lebih dikarenakan praktis sejak reformasi, PT. INTI tidak lagi memiliki produk andalan. Hal ini pun berdampak pada minimnya prestasi PT. INTI. Ketiga indikator ini menunjukkan bahwa dimensi kejelasan arah organisasi sudah berada di dalam kategori baik, dengan nilai 479.

Pengukuran dimensi Sistem Imbalan juga sudah berada di dalam kategori baik, dengan nilai interval 448. Adapun indikator yang diukur adalah kesesuaian imbalan yang diperoleh terhadap beban pekerjaan yang diberikan, penghargaan atas prestasi kerja karyawan, serta profesionalitas dalam sistem promosi jabatan. Salah satu indikator yang patut mendapat sorotan adalah perihal promosi jabatan. Sebanyak 59,52\% responden menyatakan kurang dan tidak setuju dengan statement promosi jabatan dilakukan secara profesional. Hal ini dikarenakan promosi kepangkatan, jabatan dan mutasi lebih ditentukan oleh factor kedekatan antara karyawan dengan pimpinan/manajer suatu divisi.

Pengukuran dimensi tanggung jawab menunjukkan bahwa dimensi ini sudah berada di dalam kategori sangat baik, dengan nilai interval 384. Meskipun mengetahui bahwa PT. INTI sudah lama tidak memiliki produk unggulan dan sering terjadi pergantian pimpinan puncak, namun tanggung jawab ratusan karyawan di dalamnya untuk melaksanakan tugas masih tergolong sangat baik. 
Pada pengukuran dimensi semangat kerja kelompok, diketahui bahwa dimensi ini sudah berada pada kateogori sangat baik, dengan nilai interval 497. Dua indikator yang menentukan pada dimensi ini adalah identitas bersama yang menunjang kekompakan dan kebersamaan serta optimisme yang tinggi akan masa depan perusahaan. Untuk kedua indikator ini, mayoritas responden menyatakan sikap optimis yang tinggi dan merasakan kekompakan dan kebersamaan di dalam perusahaan. Terakhir, pada dimensi standar kerja, penilaian sudah tergolong baik dengan nilai interval 453. Adapun indikator yang diukur adalah adanya prosedur kerja yang jelas untuk setiap pekerjaan yang diberikan, dukungan manajemen secara optimal, serta arahan dari manajer kepada karyawan.

Berdasarkan akumulasi seluruh nila interval pada variable iklim organisasi, dapat ditarik kesimpulan bahwa iklim organisasi PT. INTI sudah berlangsung dengan baik, dengan nilai 2225. Hanya saja, beberapa indikator pada beberapa dimensi masih belum optimal di dalam mendukung terciptanya iklim organisasi yang baik, yakni rendahnya pemahaman karyawan akan nilai budaya perusahaan, penilaian terhadap kemajuan perusahaan, kejelasan arah perusahaan serta dukungan manajemen yang masih perlu dibenahi.

Pengukuran untuk variabel Kinerja Perusahaan, terdapat 4 (empat) dimensi yang diukur, yakni quality of work (kualitas kerja), promptness (pemanfaatan waktu), initiative (inisiatif), communication (komunikasi), serta capability (kapabilitas). Pengukuran pada dimensi kualitas kerja menunjukkan hasil kurang baik, dengan nilai 306. Hal ini lebih dikarenakan mayoritas karyawan $(52,37 \%)$ menyatakan tidak ada penyusunan prioritas dalam melaksanakan tugas. Penyebab utamanya adalah terlalu seringnya berganti pimpinan dan perombakan divisi, sehingga karyawan harus mengerjakan beragam pekerjaan berbeda dan terus berubah dalam durasi waktu yang cepat. Selanjutnya, pengukuran pada dimensi promptness (ketepatan waktu) sudah berada pada kategori baik, dengan nilai 480 .

Salah satu indikator yang masih perlu dibenahi adalah efisiensi waktu di dalam penyelesaian tugas. Mayoritas karyawan (49,99\%) menyatakan mereka kurang begitu memperhatikan efisiensi waktu dalam penyelesaian tugas pekerjaan. Sementara itu, pengukuran dimensi initiative (inisiatif) menunjukkan kategori kurang baik. Dua indikator yang diukur pada dimensi ini adalah inisiatif karyawan dalam mencari solusi atas setiap kendala yang ditemu dalam bekerja dan kepeduluan pada kemajuan perusahaan.

Untuk indikator kedua, mayoritas karyawan (52,37\%) menyatakan bahwa mereka cenderung apatis terhadap perkembangan perusahaan. Hal ini sejalan dengan penilaian kejelasan arah perusahaan yang juga dinilai bermasalah pada pengukuran di atas. Sikap apatis karyawan lebih disebabkan karena tidak adanya kejelasan kebijakan dan kepemimpinan dalam waktu yang cukup lama meskipun pada dasarnya, semangat kerja kelompok dan optimisme mereka terhadap keberlangsungan perusahaan masih tetap tinggi. Dimensi terakhir yang diukur adalah communication (komunikasi). Pengukuran pada dimensi ini menunjukkan nilai kurang baik, dengan nilai 401. Tiga indikator yang diukur untuk dimensi ini adalah komunikasi informal antar karyawan, kehangatan hubungan kerja, perhatian perusahaan terhadap aspirasi karyawan. 
Untuk dua indikator terakhir, mayoritas karyawan (72,32\%) sepakat menyatakan bahwa tingkat senioritas masih tinggi di PT INTI. Hal ini menyebabkan ketidaknyaman dalam bekerja terutama bagi karyawan baru. Kehangatan hubungan kerjapun sulit dicapai. Sebagai efek domino berikutnya, penyampaian ide, saran, aspirasi dan masukan karyawan baru kepada perusahaan tidak tersalurkan dengan baik. Sekitar 69,04\% karyawan menyatakan sepakat bahwa aspirasi karyawan tidak diperhatikan oleh perusahaan.

Terakhir, pengukuran dimensi capability (kapabilitas) sudah berada pada kategori baik, dengan nilai 440. Adapun indikator yang diukur untuk dimensi ini adalah penguasaan bidang pekerjaan, pendidikan/pelatihan berkala yang merata, serta kemampuan karyawan menyesuaikan diri. Untuk indikator pendidikan/pelatihan berkala, mayoritas karyawan $(66,66 \%)$ menyatakan pendidikan dan pelatihan belum diiberikan secara merata kepada seluruh karyawan.

Akumulasi pengukuran seluruh dimensi pada variabel Kinerja Perusahaan menunjukkan kategori sudah baik, dengan nilai interval 1937. Namun demikian, dua dimensi yang masih perlu dibenahi adalah quality of work, communication serta initiative.

Untuk menjawab rumusan masalah di dalam penelitian ini, dilakukan olah data menggunakan bantuan program SPSS melalui analisis regresi. Berdasarkan olah data tersebut, diketahui nilai standardized coeficients pada kolom beta sebagai penentu nilai variabel $X$ adalah 0,688. Sementara itu, pada tabel coefficients tersebut, kolom B sebagai penentu constanta variabel $\mathrm{Y}$ diketahui nilai 5,539. Dengan demikian, dapat diketahui bahwa nilai $a=5,53$ dan $b=0,688$. Jika nilai-nilai ini dimasukkan ke dalam persamaan regresi linear sederhana, dapat diperoleh persamaan sebagai berikut: $Y=5,53+0,688$. Persamaan ini berarti koefisien regresi sebesar 0,688 menyatakan bahwa setiap pernambahan (karena tanda+) satu skor atau nilai iklim organisasi akan memberikan kenaikan skor sebesar 5,53. Untuk lebih lengkapnya, berikut disajikan tabel 4.47 coefficient hasil pengolahan data SPSS tersebut.

Tabel 1. Koefisien Regresi Pengaruh Iklim Organisasi terhadap Kinerja pada PT. INTI Persero Bandung

\begin{tabular}{llllll}
\hline Model & \multicolumn{2}{c}{$\begin{array}{c}\text { Unstandardized } \\
\text { Coefficients }\end{array}$} & $\begin{array}{c}\text { Standardized } \\
\text { Coefficients }\end{array}$ & t & sig \\
\hline 1 (Constant) & 5.539 & 5.350 & & 1.035 & .307 \\
$\mathrm{X}$ & .753 & .126 & .688 & 6.000 & .000 \\
\hline
\end{tabular}

(Sumber: Olahan Peneliti, 2010)

Dengan mengacu kepada hipotesis yang diajukan sebelumnya, yakni, jika nilai probalitas 0,15 lebih kecil atau sama dengan nilai probabilitas Sig atau [0,15 kecil sama Sig) maka Ho diterima dan Ha ditolak. Begitu juga sebaliknya. Dari persamaan di atas dapat dijelaskan bahwa koefisien regresi bernilai signifikan. 
Kesimpulan akhir yang dapat diambil adalah bahwa iklim organisasi berpengaruh positif dan signifikan terhadap kinerja karyawan PT. INTI Persero Bandung.

\section{Penutup}

Berdasarkan rumusan masalah dan hipotesis yang diajukan, penulis dapat mengambil kesimpulan sebagai berikut:

1) Seluruh dimensi iklim organisasi dilihat dari sudut pandang teori yang dikemukakan Lily M. Berry yakni "kejelasan arah, imbalan, tanggung jawab, semangat kerja kelompok serta standar kerja" sudah berada dalam kategori baik. Artinya, aspek-aspek dalam iklim organisasi telah tercapai dengan baik namun di sisi lain masih terdapat beberapa indikator untuk beberapa dimensi yang belum tercapai secara optimal.

2) Kinerja karyawan PT. INTI Persero Bandung dilihat dari dimensi kinerja yang dikemukakan oleh TR. Mitchel yaitu "quality of work (kualitas kerja), Promtness (ketepatan waktu), Initiative (inisiatif), communication (komunikasi) serta capability (kapabilitas)" sudah berada dalam kategori baik. Artinya, beberapa aspek dalam kinerja sudah tercapai dengan baik meskipun pada beberapa dimensi masih terdapat indikator yang belum optimal dilaksanakan.

3) Melalui analisis regresi linear sederhana dapat diketahui bahwa terdapat pengaruh yang positif antara iklim organisasi terhadap kinerja karyawan PT. INTI Persero Bandung. Perolehan hasil perhitungan statistik menunjukkan $Y=5,53+0,688 \mathrm{X}$. Artinya, koefisien regresi sebesar 0,688 menyatakan bahwa setiap penambahan (karena tanda+) satu skor atau nilai iklim organisasi akan memberikan kenaikan skor sebesar 5,53. Pengaruh tersebut teruji signifikan. Kesimpulan akhir yang dapat diambil adalah terdapat pengaruh yang positif dan signifikan antara iklim organisasi PTINTI Persero terhadap kinerja karyawan PT INTI Persero Bandung. Dengan demikian dalam penelitian ini Ha diterima dan Ho ditolak.

\section{DAFTAR KEPUSTAKAAN}

Berry, Lily M. (2001). Psychological at Work. Singapore: Mc Graw Hill.

Salusu, J. (2006). Pengambilan Keputusan Strategik. Jakarta: PT. Gramedia.

Sedarmayanti. (2001). Sumber Daya Manusia dan Produktivitas Kerja. Bandung: Mandar Maju.

Simamora, Henry. (2006). Manajemen Sumber Daya Manusia: Yogyakarta: STIE YKPN.

Wibowo. (2007). Manajemen Kinerja. Jakarta: PT. Rajagrafindo Persada.

Wirawan. (2007). Budaya dan Iklim Organisasi: Teori Aplikasi dan Penelitian. Jakarta: Salemba Empat. 
Annual Report PT INTI 2005.

Annual Report PT INTI 2006.

Annual Report PT INTI 2007.

Harian Media Indonesia, Edisi Juli 2007. 